\title{
Kruiden zijn nuttig en onmisbaar
}

Keywords kruiden

In Drugs schreef Peter De Smet over de huidige en toekomstige plaats van geneesmiddelen, afgeleid van planten en schimmels, in de officiële academische geneeskunde. Heel wat geneesmiddelen hebben hun wortels in de plantenwereld (tabel 3 in het artikel) en botanische zoektochten kunnen nog meer opleveren. Onderzoek uitgaande van plantenextracten blijft extra moeilijk.

\section{Literatuur}

De Smet P. Drugs 1997; 54: 801-40. 